\title{
Effective Engagement of Modern Gadgets in Workplace
}

\author{
G. Santhoshkumar, Velanganni, S. Robin
}

\begin{abstract}
Organizations with highly-engaged employees routinely outperform those with greater numbers of disengaged employees. Not only do they post higher earnings, they also recover more quickly from market-induced setbacks. Therefore, it seems self-evident that organizations would be interested in taking every possible step to keep their employees fully motivated and educated. Low satisfaction rates lead to lower productivity and increase the likelihood of turnover, resulting in many potentially talented workers moving elsewhere for more attractive opportunities. Fortunately, most approaches can be adopted by organizations to help improve engagement.
\end{abstract}

\section{INTRODUCTION}

Employee morale is the stage of dedication and engagement that an employee has towards their corporation and values. An involved employee is aware of the business context and works for the good of the organization with his colleagues to improve performance in the workplace.

A. DEFINITION:

The earlier statement of Scarlett Surveys, "Employee Engagement is a measureable degree of an employee's positive or negative emotional attachment to their job, colleagues and organization which profoundly influences their willingness to learn \& perform at work". [1]-[5]

\section{OBJECTIVES OF THE STUDY}

To determine the positive attitude of the worker towards their job.

To evaluate the degree in which the employee are engaged in the workforce.

To analyze a good connection between administration and the recruits.

To analyses the various factors leading to employee engagement.[6]-[10]

Revised Manuscript Received on December 30, 2019.

G. Santhoshkumar, Assistant professor, Department of Science and Humanities, Bharat Institute of Higher Education and Research ,Chennai, India. .Email santhoshravi671026@gmail.com

R. Velanganni, Assistant professor, Department of Science and Humanities ,Bharat Institute of Higher Education and Research ,Chennai, India. .Email velangannijose78516@gmail.com

S. Robin, Assistant professor, Department of Science and Humanities, Bharat Institute of Higher Education and Research ,Chennai, India.

\section{RESEARCH METHODOLOGY}

A. Research Design:

The study conducted is Descriptive in nature.

\section{Data Collection Method:}

\section{A. Primary and secondary Data:}

Primary data are gathered through inspection from the employees and the later was gathered from journals and previous research studies.

\section{B. Statistical Tool:}

\section{Weighted Average Method}

Weighted Average Method:

Net score in $\%$ age $=$ net score in row / total net score X 100

\section{WEIGHTED AVERAGE METHOD}

The table 1 showing that the involvement helps to develop the effectiveness of the organization.

\begin{tabular}{|l|l|l|l|}
\hline Particulars & $\begin{array}{l}\text { No of respondents } \\
(\mathbf{X})\end{array}$ & $\mathbf{R a n k}(\mathbf{Y})$ & $\mathbf{X} \star \mathbf{Y}$ \\
\hline Strongly Agree & 29 & 5 & 145 \\
\hline Agree & 64 & 4 & 256 \\
\hline Neutral & 7 & 3 & 21 \\
\hline Disagree & 0 & 2 & 0 \\
\hline Strongly Disagree & 0 & 1 & 0 \\
\hline Total & & & 422 \\
\hline
\end{tabular}

Total $=422 / 100=4.22$

$>$ The weighted average value is 4.22

\section{RESULTS \& DISCUSSION}

$>89 \%$ of respondents are $<25$ years of age.

$>73 \%$ of respondents are belongs to diploma.

$>79 \%$ of the respondents are below 5000 of income level.

$>64 \%$ of the respondents agree that the involvement help to develop the effectiveness of the organization.

$>77 \%$ of respondents says that they are highly interested at all time to the job designed for them.

$>88 \%$ of respondents says that they are exited about their work and focus on accomplishing the task. 
$69 \%$ of respondents defiantly would develop a good relationship between employee and management.

$>69 \%$ of respondents says that they find obstacles in achieving their target.

$>50 \%$ of respondents agree that workload is reasonable.

$>67 \%$ of respondents frequently aware of existing situation and current problem in your organization.

$>59 \%$ of respondents feel that the management is flexible.

$>53 \%$ of the respondents are usually ready to work extra hours and eager to volunteer for different assignments.

$>61 \%$ of respondents feel the benefits offered by the organization are good.[11]-[15]

\section{SUGGESTIONS}

$>$ For further improvements of organization commitment the following suggestions can be utilized:

$>$ Based on my study the respondents of the organization can improve the flow of information regarding current problems in the organization.

$>$ Based on my study there is many obstacles in achieving their target because the customer are unaware of your store.

$>$ Based on my study some of the respondents are usually ready to work in extra hours and eager to volunteer for different assignments, so the company has to focus more on those employees by assigning flexible work and helps them to increase their capability in their job. Since that the other employee will also get motivated.

$>$ Based on my study some of the respondents feels that their nature of job is affecting their work involvement. so the company has to give more importance in allocating work to the employees. They have to check whether the job is handed to the suitable employee or not. [16]-[20]

\section{CONCLUSION}

A learn about on evaluation of worker engagement is carried among the employee of future fee retail. Management's basic job is the effective utilization of human assets for achievements of organisation objective. Employee engagement is an necessary function for each and every worker to accomplish the goals of an organization. The most important goal of the find out about is to identify the stage of dedication and involvement of an employee has toward agency and its value [21]-[25]

\section{REFERENCES}

1. Vasanthi, S. \& Rabiyathul Basariya, S. 2019, "Influence of value analysis and cross training in industry", International Journal of Engineering and Advanced Technology, vol. 8, no. 6, pp. 1810-1811.

2. Velvizhi, R., Sri Gowtham, S. \& Jeya Priya, D. 2019, "Examination of early feedbacks for effective product retailing on E-commerce websites", International Journal of Engineering and Advanced Technology, vol. 8, no. 6 Special Issue 2, pp. 703-706.

3. Anuradha, C., Pothumani, S. \& Kavitha, R. 2019, "A novel method towards E-commerce", International Journal of Engineering and Advanced Technology, vol. 8, no. 6 Special Issue 2, pp. 535-538.

4. Thomas, J. \& Rabiyathul Basariya, S. 2019, "A study on the issues of financial ratio analysis", Indian Journal of Public Health Research and Development, vol. 10, no. 3, pp. 1079-1081.
5. Ramachandran, S. \& Rabiyathul Basariya, S. 2019, "Online marketing - study on customer satisfaction and relationship", Indian Journal of Public Health Research and Development, vol. 10, no. 3, pp. 1072-1078.

6. Priya, R., Vinothini, G. \& Cor Jesu, C.D. 2019, "The mentor-protégé relationship for professional growth", Journal of Advanced Research in Dynamical and Control Systems, vol. 11, no. 9 Special Issue, pp. 1110-1119.

7. Jannifer Rani, N., Bina Pani, S. \& Nimisha, N.S. 2019, "A study on money back polices available in LIC", Journal of Advanced Research in Dynamical and Control Systems, vol. 11, no. 9 Special Issue, pp. 833-839.

8. Saillaja, V., Jhansi Rani, K. \& Catherine, R. 2019, "Global marketing management planning and organization", Journal of Advanced Research in Dynamical and Control Systems, vol. 11, no. 9 Special Issue, pp. 489-493

9. Saillaja, V., Jhansi Rani, K. \& Catherine, R. 2019, "The new phase of marketing information system", Journal of Advanced Research in Dynamical and Control Systems, vol. 11, no. 9 Special Issue, pp. 482-488.

10. Thoufiqulla \& Raju, D.V. 2019, "Perception of indian investor towards investment in mutual funds with special reference to mip funds", Journal of Advanced Research in Dynamical and Control Systems, vol. 11, no. 5, pp. 177-183.

11. Jasmine, K.R.M. \& Basariya, S.R. 2018, "A study on the customers benefits on mutual funds", International Journal of Civil Engineering and Technology, vol. 9, no. 4, pp. 45-48.

12. Vasanthi, S. \& Basariya, S.R. 2019, "Pros and cons of on the job training versus off the job training", International Journal of Scientific and Technology Research, vol. 8, no. 10, pp. 671-674.

13. Pavithra, J. \& Ganesan, M. 2016, "A study on awareness and impact of micro-financial schemes", International Journal of Applied Business and Economic Research, vol. 14, no. 8, pp. 5449-5460.

14. Pavithra, J., Dilli Babu, P. \& Ambuli, T.V. 2014, "A study on budgetary control at Maruti Service Masters, Chennai", International Journal of Applied Business and Economic Research, vol. 12, no. 2, pp. 151-161.

15. Gunaraja, T.M. \& Venkatrama Raju, D. 2018, "Determining factors of organisational climate with reference to leadership styles", International Journal of Mechanical Engineering and Technology, vol. 9, no. 9, pp. 1327-1332.

16. Gunaraja, T.M. \& Venkatrama Raju, D. 2018, "The role of job satisfaction and training of employees in determining organisational climate of a selected industry", International Journal of Civil Engineering and Technology, vol. 9, no. 8, pp. 1266-1269.

17. Aarathy, T.S. \& Raju, D.V. 2018, "Performance appraisal and its effects on employees with respect to it sector in Chennai city", International Journal of Civil Engineering and Technology, vol. 9, no. 6, pp. 1535-1538.

18. Aarathy, T.S. \& Raju, D.V. 2018, "Employee perception towards performance appraisal system in IT sector", International Journal of Mechanical Engineering and Technology, vol. 9, no. 5, pp. 131-135.

19. Porselvi, W., Jublee, D. \& Sivanesan, G. 2018, "A study on factors influencing adoption of technology and innovation in banking industry, tamilnadu, India", International Journal of Mechanical Engineering and Technology, vol. 9, no. 5, pp. 789-800.

20. Akessa, G.M. and Dhufera, A.G., 2015. Factors That Influences Students Academic Performance: A Case of Rift Valley University, Jimma, Ethiopia. Journal of Education and Practice, 6(22), pp.55-63.

21. Miller, G. and Shih, C.C., 1999. A faculty assessment of the academic rigor of on-and off-campus courses in agriculture. Journal of Agricultural Education, 40, pp.57-65.

22. Tsinidou, M., Gerogiannis, V. and Fitsilis, P., 2010. Evaluation of the factors that determine quality in higher education: an empirical study. Quality Assurance in education, 18(3), pp.227-244.

23. Farooq, M.S., Chaudhry, A.H., Shafiq, M. and Berhanu, G., 2011. Factors affecting students' quality of academic performance: a case of secondary school level. Journal of quality and technology management, 7(2), pp.1-14.

24. Fitsilis, P., Gerogiannis, V. and Anthopoulos, L., 2014. Ontologies for software project management: a review. Journal of Software Engineering and Applications, 7(13), p.1096.

25. Adams, J.D. and Jaffe, A.B., 1996. Bounding the effects of R\&D: an investigation using matched establishment-firm data(No. w5544). National bureau of economic research.

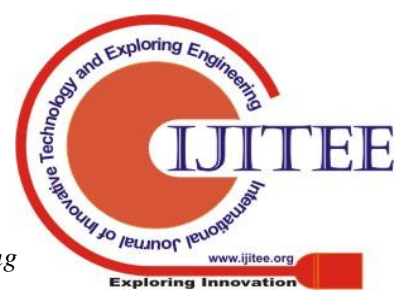




\section{AUTHORS PROFILE}

G. Santhoshkumar, Assistant professor, Department of Science and Humanities, Bharat Institute of Higher Education and Research ,Chennai, India. .

R. Velanganni, Assistant professor, Department of Science and Humanities,Bharat Institute of Higher Education and Research ,Chennai, India

S. Robin, Assistant professor, Department of Science and Humanities, Bharat Institute of Higher Education and Research ,Chennai, India 